\title{
VISUAL SEMIOTICS OF FEMININE FASHION: A CONCISE ANALYSIS
}

\author{
Konstantin Sharov \\ Lomonosov Moscow State University, Russia \\ const.sharov@mail.ru
}

In the paper, the structure, composition and properties of feminine vestimentary fashion as a visual symbolic system, are studied. It is found out that the system of female fashion cannot be deduced as a simple derivative of the costume design either in synchronic or diachronic (historical) aspect. The methodology used in the work includes techniques and methods of semiotic analysis proposed by R. Barthes, Prince N. Trubetzkoy, L. Hjelmslev, A. Martinet and Ch. Peirce. It is shewn that throughout the history the semiotic potential of fashion has always been unevenly distributed between the two genders. The man has always considered clothing exclusively as an object of use and necessity, while on the basis of the costume design, the woman was able to create a complex visual semiotic system of fashion completely separate and unrelated to the costume design directly. The real clothing, conditioned by its goals and purposes, does not mean anything. Women's fashion, by contrast, means and represents, encodes and transposes the meanings and denotes and connotes the signifiers. Feminine fashion simulates symbolic and social reality and builds a new world of the imaginary, drawing horizons of appearances and expanding the semantic foundations of the phænomenology of clothing. In general, female fashion system is as complex as the real clothes are simple. Even in the extreme case of nudity, female nakedness transforms to a semiotic system. An approach to the classification of visual signs of women's fashion is proposed, according to which these signs with respect to mobility can be a) static, b) dynamic and c) static-dynamic. According to the message of meaning aimed at the recipient, the signs can be divided into: i) semantic signs, ii) signs-ciphers, which, in turn, are divided into ii, $\alpha$ ) purely cryptographic signs and ii, $\beta$ ) simulacra, and iii) signs-imperatives. It is revealed that the semiotic chains built by women's fashion can be of four levels: 0 ) the level of expediency, 1) main denotative level, 2) level of symbolic ritual tradition (level of initial connotation of meanings), 3) level of fashion mythology (an aggregate of many levels of subsequent connotation of meanings).

Keywords: fashion, feminine fashion, vestimentary code, visual vestimentary sign, semiotics of fashion. 


\title{
ВИЗУАЯЬНАЯ СЕМИОТИКА ЖЕНСКОЙ МОДЫ: КРАТКИЙ АНАЛИЗ
}

\author{
К. С. Шаров \\ Московский государственный университет им. М. В. Ломоносова, Россия \\ const.sharov@mail.ru
}

В данной работе исследуются структура, состав и свойства женской моды в одежде как визуально-знаковой системе. Установлено, что система женской моды не может быть выведена как простое производное от дизайна костюма ни в синхроническом, ни в диахроническом (историческом) аспекте. Метододогия, исподьзованная в работе, включает приёмы и методы семиотического анализа, предложенные Р. Бартом, Н. Трубецким, А. Эльмслевом, А. Мартине и Ч. Пирсом. Показано, что семиотический потенциал моды на протяжении истории всегда был неравномерно распределён между гендерами. Мужчина в основном всегда рассматривал одежду исключительно как предмет пользы и необходимости, в то время как женщина на основе дизайна костюма создала совершенно отдельную и не связанную напрямую с ним визуально-семиотическую комплексную систему. Реальная одежда, обусловленная своими целями и назначениями, ничего не означает. Мода, наоборот, означает и обозначает, шифрует и транспонирует смыслы, денотирует и коннотирует означающие. Она симулирует знаковую и социальную реальность и строит новый мир воображаемого, рисуя горизонты видимостей и расширяя смысловые основы феноменологии одежды. В целом система женской моды так же сложна, как проста реальная одежда. Даже в предельном случае отсутствия одежды женская нагота превращается в семиотическую систему. Автор предлагает такой подход к классификации визуальных знаков женской моды, согласно которому эти знаки относительно подвижности могут быть: а) статическими, б) динамическими и в) статико-динамическими. По донесению до реципиента смысла знаки могут делиться на: I) смысловые знаки, II) знаки-шифры, которые, в свою очередь, подразделяются на II $\alpha$ ) чисто криптографические знаки и II $\beta$ ) симулякры, и III) знаки-императивы. Выявлено, что семиотические цепочки, выстраиваемые женской модой, могут быть четырёх уровней: 0) уровня целесообразности, 1) основного денотативного уровня, 2) уровня знаково-символической ритуадьной традиции (уровня начальной коннотации смыслов), 3) уровня мифологии моды (совокупность многих уровней последующей коннотации смыслов).

Кдючевые слова: мода, женская мода, вестиментарный код, визуальный вестиментарный знак, семиотика моды.

DOI 10.23951/2312-7899-2019-1-173-195 
They say in vain that the oracles' mouths speak truth. But the others also say in vain that all the oracles are incorrigible liars. They neither speak truth, nor lie, they just shew us signs.

Heraclites of Ephesus

\section{Introduction}

Famous American nominalist Nelson Goodman, giving his lectures on æsthetics at the University of Massachusetts, proposed to supersede an essentialist problem in aesthetics "what is art?" by an intentional question "when is art?" [Goodman 1972, 35]. The same question can be rightfully asked in semiotics: when is the sign? and when is the message? When does an object or act become meaningful and not just natural or functional? When does a thing start to mean something?

This problem is extremely important in visual semiotics of clothing and fashion, and it is no coincidence. Most theorists agree that fashion differs from simple costume design primarily in its semiotic nature [Barthes 2003, 44; Bourdieu 1975, 28; Eco 1998, 64-65]. The ancient Greeks coloring human and god's statues may be regarded as putting the vestimentary signs to the art, as Anna Afonasina argues [Afonasina 2014, 32; Afonasina 2018, 281, 284]. Timothey Myakin points out the significance of vestimentary signs and codes interpretation in the Greek mythology [Myakin 2018, 355; Myakin 2019, 161]. Irina Protopopova and Alexey Garadja [Protopopova, Garadja 2018, 436], Michiel Meeusen [Meeusen 2018, 32], Eleni Panagiotarakou [Panagiotarakou 2019, 22, 26] draw one's attention to the fact that in Ancient Greece theatre, art and poetry often considered vest codes as main structural elements of a work of art. Mikhail Vedeshkin and Konstantin Sharov underline the same tendency in the Ancient Roman culture [Sharov, 2019, 110; Vedeshkin 2018, 263-264]. Demonstrating different types of clothes fashion in cinematography has obviously semiotic goals, as several researchers prove in their works [Bernatonite 2016; Bernatonite 2017; Dogo 2015; Dulgheru 2014; Khitruk 2017]. Sergey Avanesov shews that visual semiotics in iconography deals mainly with clothing [Avanesov 2018 , 525]. Fashion is a semiotic social system, while clothing refers only to the phænomenal world. A study of fashion, i.e. phænomenon represented (and sometimes imagined) and constructed at the strategic and tactical levels of clothing, gives a direct methodological advantage over an analysis of real phænomenological clothing. In contrast to the 
semiotic structure of clothing-image and linguistic structure of clothingdescription (fashion elements), the structure of real clothing can be merely technological, which was noted by Prince Nikolai Trubetzkoy in one of the chapters of his work on phonology, devoted to a semantic analysis of real clothing [Troubetzkoy 1949, 11-14]. Units of symbolic clothing-image belong to sphere of signs and visual forms, while units of clothing-description to sphere of words. Units of real clothing cannot refer to language, because language is not a semantic representation of phænomenal reality, nor to signs and visualization, because the "visibility" of a real thing does not exhaust its reality, and even more so its structure [Barthes 1975, 71; Martinet 1960, 21, 85-86]. To analyze a real detail of clothing in a fairly formal concepts, it is necessary to turn to the actions that determined its manufacturing, cutting and sewing technologies, which, of course, goes beyond any philosophical discourse. Although both fashion and costume design are art, real clothing is involved in the art of technology, and fashion in the art of imagination.

\section{Irreducibility of feminine fashion to costume design}

If a fundamental difference between costume design and fashion consists precisely in this fact, then fashion can be derived from the phænomenology of clothing neither deductively nor historically. Thus, answering the question posed at the very beginning of the paper, I can say that a detail of the costume begins to mean something only when it becomes a part of fashion, moving into it from a phænomenal reality located in a much narrower hermeneutic horizon. At the same time, fashion is not constructed on the basis of real clothes as a higher system in the semantic aspect, but it is initially created as an ideal visual semiotic space. This space (a kind of Hyperuranion of signs) is not a copy of reality, but it structures, constructs and imagines reality and a set of meanings in completely different parts of social life.

Most often, researchers of culture of fashion ask essentialist questions "when was fashion born?", "how to develop fashion?", "how to predict the change of styles in fashion?" etc. In their research, fashion is almost never considered as a tool of social transformation carried out through the semiotic sphere. A main task of a designer-artist is announced as "to predict constantly emerging novel things that can be already felt in the air, but have not yet found their embodiments" [Obraztsov 1978, 53], but the researchers and analysts never thought of a costume designer as 
of a semiotic planner and, additionally, a social planner. Intentional questions are rarely asked such as "who, how, when and why organizes the system of fashion?" It is in responses to them that an adequate understanding of fashion hides as a visual semiotic system.

A typical example of an evolutionary-historical and at the same time deductive approach to the analysis of fashion can be found in a study of the real costume performed by E. V. Kireeva. She distinguishes four historical stages of evolution of human clothing:

1) the stage of semi-wild nudity,

2) the stage of purely functional clothing,

3) the stage of clothing design and

4) the stage of fashion itself

[Kireeva 1976, 13-32].

This evolution, according to another Russian researcher Zborovsky, led to a gradual process of development of the socio-economic base of the primitive society [Zborovsky 1988, 5]. Trying to determine the time frame of each stage, Kireeva and Zborovsky seem to face a serious problem: when can a period of fashion itself be found? The author's delusion, in my opinion, is obvious. It comes from an attempt to introduce a universal temporal logic in diachronic variations of fashion. All studies based on the principle of deduction of fashion from diachronic changes in clothing styles appear to fail sooner or later.

But what if we consider fashion in the synchronic aspect and do not connect its transformation with the socially determined needs of real clothes? What if not society primarily influences fashion, but fashion influences society? Indeed, Roland Barthes noted that synchrony of fashion within a certain time interval (for Barthes it is, for example, a year, although this period may be different) is absolute and even unique, and such synchrony does not occur in linguistic (natural) languages [Barthes 2003, 41]. During this period, fashion is stable and open to semiotic analysis much better than some natural language open to linguistics. On the other hand, if fashion is indeed deduced, albeit indirectly, by the logic of pragmatism from the systems of phænomenological clothing, how can we explain that the "rude and ignorant" primitive man suddenly began to use semiotic codes instead of primitive utilitarianism? The irreducibility of fashion to a purely rational and material world denies the deduction of fashion from clothing in itself.

Real clothing, conditioned by its goals and purposes, does not mean anything. Fashion means and represents; it is, in fact, serves exactly for these purposes. But it also encrypts and transposes the meanings. It 
denotes and connotes the meanings. It simulates symbolic and social reality and builds a new world of the imaginary, drawing horizons of appearances and undermining the semantic foundations of the phænomenology of clothing. Fashion is as complicated and confusing as the real clothes is simple. And this intricate system has historically been unevenly distributed between the sexes. Gender equality in dress styles began and ended in Paradise when God banished a man and a woman for their fall.

\section{Female nudity as a visual semiotic system}

After the expulsion of the men from Paradise, the fate of clothes as a sign underwent a radical gender transformation. The man, having forgotten or not understood correctly a symbolic meaning of clothes, began to consider them exclusively as an object of use and need. But the woman who possibly became increasingly aware of the value of net significance of clothing, were able to establish a system of fashion. However, the importance and significance of the female as a signgenerating and sign-ordering force in the contemporary academic research, remains often blurred by considerations of anatomy and physiology.

Seyla Benhabib, a modern American sociologist, in her 2002 work notes that "women... mediate between nature... to which we all belong, and a symbolic order that transforms us into cultural beings", but makes an amendment fatal for a woman: "just because of her ability to bear children" [Benhabib 2002, 100-103]. So, it turns out that the anatomy is a fate, as Sigmund Freud claimed? The fatality that destined a woman to be only a female, albeit partially "cultured", a female mediator between culture and the animal world?

Fashion can serve some refutation to this Freud's concept. In this regard, women's fashion should be understood as a primordial and almost perennial phænomenon that did not arise in a certain historical period as a result of the inclusion of costume design to semiotic scope. At the same time, men's fashion is also a direct or indirect product of the female. By and large, were it not for women, there would be no fashion as a semiotic system.

Being engaged in the construction of visual signs of her costume, the woman was able to create such semiological tricks that provided her with a real "antidote" against the vicious and sinful meaning of nudity. The woman started to use the very nudity in the sense of semiotic 
"second skin". Unlike the man whose body, according to a witty remark of Baudrillard, is a "cemetery of signs" [Baudrillard 1976, 192], the woman made her body a field of signs. She transformed the semiotic system associated with her naked body into a limitless connotation ${ }^{1}$ and transposed it into the realm of a myth (this will be described in more detail below). Because of this, all the depravity signified by the men, corresponding to the sign of nudity of the female body, was stolen by super-connotative sign of a higher order. So we may hardly complain like feminist author Luce Irigaray does: "the feminine remains the place deprived of its place... This ethical question defines the point of view on nudity and depravity related to it. When a woman is naked, she is deprived of a place, her own place" [Irigaray 1984, 18].

A man could not deprive a woman of her place in visual semiotics of fashion throughout the history of human society. The woman completely eliminated the very depravity of her nakedness, while the man tried constantly to read this depravity there. Moreover, he tried to impose on the woman herself a reflexive sense of her nudity, which, however, he never managed to implement. At the Renaissance period, which brought back to life and renewed the culture of the body, the symbolic interactionism of the female body was used to make it an object of art, while the image of the male body remained on the periphery of art. Paintings by Raphael and Botticelli, sculptures by Donatello and Michelangelo depict not just the naked body of a woman, but its sign. In this respect, the most revealing masters of the late Renaissance, such as Leonardo da Vinci, Titian, Tintoretto, Veronese and Bassano whose paintings that embodied scenes of ancient life and included elements of female (but not male) nudity, are the most difficult in terms of semiotic analysis. "The birth of Venus" of Sandro Botticelli may give us an example: not Venus-debauchery, but modest Venus whose body is just a sign of pure art that completely eliminates any eroticism from the visual sign. The Renaissance masters neither created, nor opened, but merely demonstrated the symbolic nature of the myth of female nudity.

Elevated to the rank of a myth of the void, the endless symbolic connotation of female nudity did not identify itself with enticement and desire. It was in ancient times that clothing appeared, now called nudelook, i.e. simulating nudity, aimed precisely at such a denotation. Female clothing, even a la negligée, can be denoted in some way (for example,

\footnotetext{
${ }^{1}$ According to Louis Hjelmslev, connotation is a transformation of the sign, in which a new sign system is built. Its plan of expression forms another sign system [Hjelmslev 1959, 283-312]. This definition reflects the semantic meaning of the connotation.
} 
denoted by eroticism), but nudity never ${ }^{2}$. The latter entered the category of myth, while the former remains a sign intended for men.

It is no coincidence that in Ovid's "Art of love" the expressions "to be almost naked", "in some clothes to be more naked than without them", etc. appear, indicating that just with the aid of the myth of nudity it is impossible to achieve the semiotic completeness of specific discrete signifieds [Martindale 1990]. Horace's Sub clara nuda lucerna ${ }^{3}$ is about the same thing. This sense of clothing a la negligée is remarkably well conveyed by Victor Hugo in his "L'Homme qui rit":

Nue à la lettre, non. Cette femme était vêtue. Et vêtue de la tête aux pieds. Le vêtement était une chemise, très longue, comme les robes d'anges dans les tableaux de sainteté, mais si fine qu'elle semblait mouillée. De là un à peu près de femme nue, plus traître et plus périlleux que la nudité franche. L'histoire a enregistré des processions de princesses et de grandes dames entre deux files de moines, où, sous prétexte de pieds nus et d'humilité, la duchesse de Montpensier se montrait ainsi à tout Paris dans une chemise de dentelle. Correctif: un cierge à la main [Hugo 2002, 525].

[As a matter of fact, she wasn't completely nude. The woman was dressed. Dressed from head to toe. She was wearing a very long shirt, like those clothes angels are depicted in, but it was so thin that it seemed wet. This half-nudity is more seductive and more dangerous than outright nudity. From the history, we know that princesses and noble ladies took part in the processes of repentance, which took place between two rows of monks; in one of these processions, the Duchess of Montpensier, under the pretext of self-abasement, demonstrated herself being clothed just in a lace shirt to the whole Paris. However, the Duchess was barefoot and with a candle in her hand $]^{4}$.

Moreover, the sign of nakedness, which a woman constructs for a man with the help of such tricks, does not carry a directive meaning: it is not an imperative sign, but a sign-cipher, just more emphatically modulated than, for example, the cleavage. "Who is she?" asked himself Gwynplaine, the main character of Hugo's novel, looking at sleeping Josiane. "A fallen woman or virgin?" Hugo replies to him: "both, because a smile of Messalina lurking in her was combined with an alertness of Diana" [Hugo 2002, 526].

\footnotetext{
${ }^{2}$ We are talking about how the woman imply certain meanings, using a symbolic pair "clothes nudity", and not about how the man treats her nudity in a utilitarian way.

${ }^{3}$ A naked woman near a bright lamp (Latin).

${ }^{4}$ The translation is mine.
} 

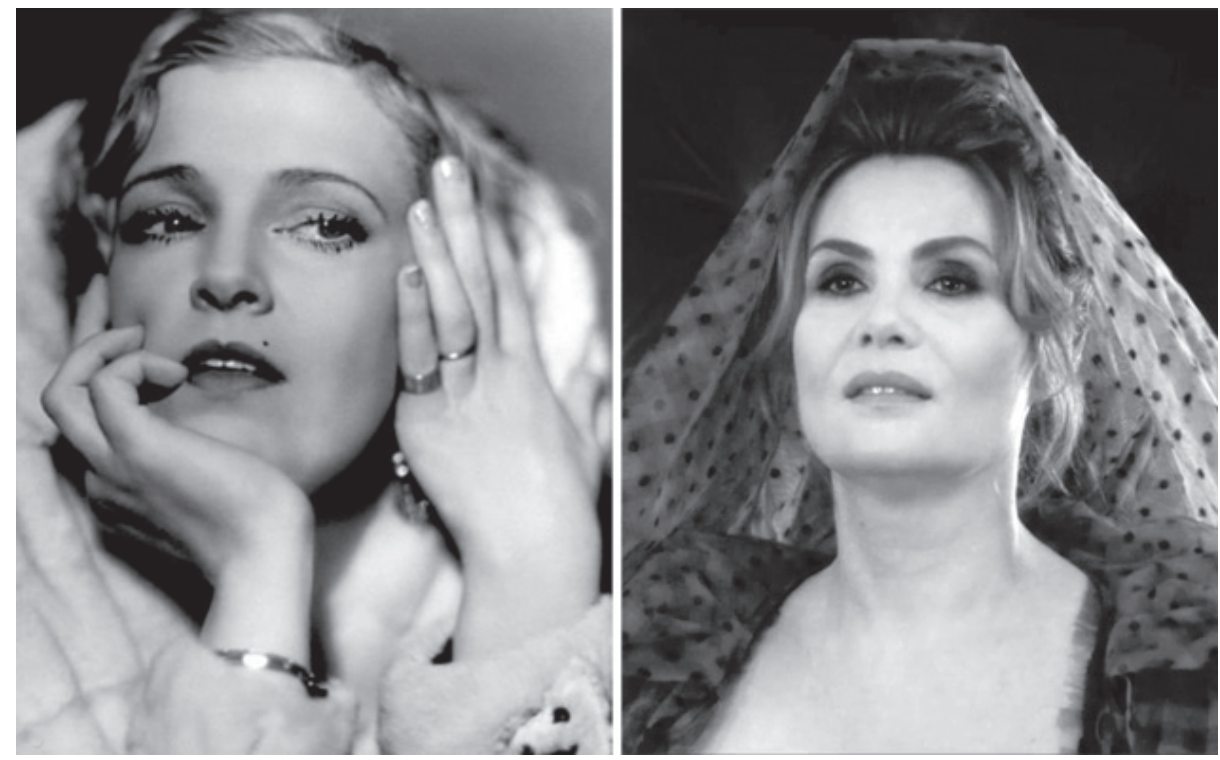

Fig. 1. Two cinematographic performances of Duchess Josiane of Hugo's "L'Homme qui rit": by Russian-American actress Olga Baklanova, 1928 US movie "The man who laughs" (in the left), and French actress Emmanuelle Seigner, 2012 French movie "L"Homme qui rit" (in the right)

But this is already a game. Where else, in addition to the game and mythology, can a woman semiotically appear both lecherous and innocent? In Roman heathen religion, Venus acted in the role of a chaste marriage's keeper, and simultaneously in the role of a lewd heroine, enticing all Olympus indiscriminately.

On the other hand, in a game in which she beat herself, Rebecca Sharp of Thackeray's "Vanity Fair" managed to combine a caring mother, passionate mistress, devoted wife and femme fatale all in one during some time. "I am innocent! Tell him, I am innocent!", Rebecca shouted to Marquess Steyne, with whom her husband Rawdon Crawley found her, urging her lover to confirm her innocence to her husband [Thackeray 1992, 303]. The paradox is that it was true, at least a part of the truth, if we ignore all the gifts of Marquess Steyne, made in the form of an advance in the hope of a worthy reward. The sign of a negligée means little for a man in itself; the man is more interested in a motive that guided the woman dressed in such clothes. What for men is a subject of desire, for women a subject of fun more often than seduction. Even orthodox Freudian Jacques Lacan recognised it [Lacan 1953]. As an illustration of this game and fun we may recall the same excerpt from Hugo's masterpiece, more precisely, an excerpt that describes the strategy of Duchess Josiane, who created a certain look for herself: 
Il y avait sur cette beauté la clarté de l'inaccessible. Pas de pureté comparable à cette forme chaste et altière. Certaines neiges qui n'ont jamais été touches sont reconnaissables. Les blancheurs sacrées de la Yungfrau, cette femme les avait. Ce qui se dégageait de ce front inconscient, de cette vermeille chevelure éparse, de ces cils abaissés, de ces veines bleues vaguement visibles, de ces rondeurs sculpturales des seins, des hanches et des genoux modelant les affleurements roses de la chemise, c'était la divinité d'un sommeil auguste. Cette impudeur se dissolvait en rayonnement. Cette créature était nue avec autant de calme que si elle avait droit au cynisme divin, elle avait la sécurité d'une olympienne qui se fait fille du gouffre, et qui peut dire à l'océan: Père! [Hugo 2002, 528].

[Something invulnerable was present in her brilliant beauty. Nothing could be compared in purity to the chastely strict forms of her body. Snow, which was never trampled by a man's foot, can be recognised immediately. This woman shone with the sacred whiteness of the Jungfrau peak. From her patient's brow, from the scattered golden hair, from lowered lashes, from the barely visible bluish veins, from the curves of her breasts worthy of the chisel of a sculptor, from hips and knees, looking pink through her diaphanous shirt, the magnificence of a sleeping goddess could be felt. Her shamelessness dissolved in the light. She was lying almost naked so calmly, accurately entitled to this divine cynicism; the self-confidence of an Olympic goddess was felt in her, which, plunging into an ocean wave, can say to the ocean, "Father!"]

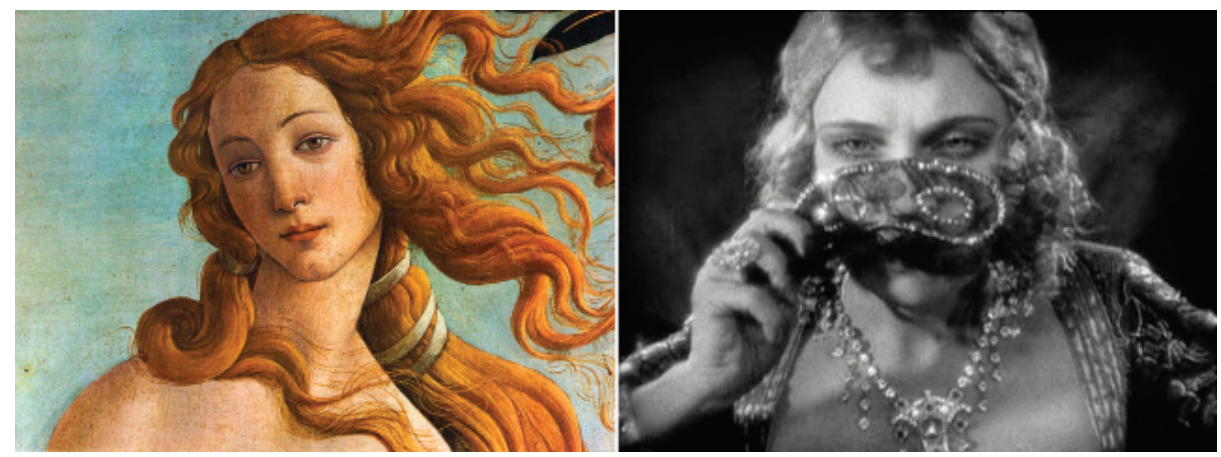

Fig. 2. Botticelli's Venus and Olga Baklanova as Duchess Josiane

Gorgeous, unattainable Josiane offered herself to all looks, all desires, all dreams, all madness, proudly resting on this bed. In the denotation of her nakedness, specifically designed for prying eyes (although she was asleep), Duchess Josiane is far superior to Venus emerging from the shell in Botticelli's famous painting in the field of practically implemented visual semiotics. In the painting, there is a vestimentary myth, denying the slightest meaning of the vice. Here, in Hugo's novel, there is an embodied and demonstrated moral corruption, but the corruption

\footnotetext{
${ }^{5}$ The translation is mine.
} 
played on the forefront of splendour and radiance. Not without reason Hugo's main character could not understand by such extravagant appearance, if the Duchess is pious or sinful.

The man of European culture could never forgive the woman for her capability to transform her body into a visual sign ${ }^{6}$, and his own inability to carry out such semiotic transformations of his nudity. Where possible, he tried to correlate a lot of various negative signifieds artificially created by him, with the sign of the naked female body. Historically everything was present here: corruption, enticement, temptation, seduction, radicalised sexuality, as well as more negative lust, depravity, obscenity, vulgarity, tendency to orgies, embodied striptease and pornography... Apparently, the Man could not give up the idea that the woman's nakedness covered with clothes, functions as a secret, ambivalent semiotic reality.

A non-European man, a representative of some traditional community, who adopted, despite the seeming absurdity of such a statement, much more from a woman in terms of semiotics, is even closer to the semiotic abilities of the woman, clothed in a symbolic shell. This man is a savage, as Jean Baudrillard mentions, for many centuries trying to make his naked body a sign that means face [Baudrillard 1980, 76-78]. He tries to represent his nudity not as an opposition to the face, but as its component. Therefore, nudity cannot seem obscene, i.e. the body cannot purposely seem naked, as in European culture a face cannot seem naked, that is already a symbolic veil in itself.

\section{An approach to the classification of feminine fashion signs}

Unlike male clothing and male fashion, whose vestimentary codes are always clearly defined (by men themselves or by the other sex, it does not matter), the semiotics of women's fashion is sometimes rather confusing and requires a comprehensive analysis. In this discourse, objects of our attention will be the signs of female pre-postmodern fashion.

In women's fashion and in the particular case of its manifestations, an individual dress, the semantic signs are interwoven with the signsciphers, developing a unified picture. However, the signs-ciphers, or cryptographic elements of the female vestimentary fashion, are not all homogeneous in their denotation. Some of them exist only to hide and

\footnotetext{
${ }^{6}$ It is no accident that Claude Lévi-Strauss noted that "the female body is a cultural and symbolic board on which human societies write their moral codes" [Lévi-Strauss 2002].
} 
make the semantic equivalent of the visual image of a woman obscure. These ones include, for example, a veil that, closing (covering or hiding) the face at a phænomenal level, hides the nature of a women at the semiotic level. However, we should not assume that only the elements of clothing that hide the body parts on the material level are signsciphers in the semiotic horizon. In this category, there would be, for example, short veils, gloves for standard applications (i.e. those that do not have a special purpose), the crinoline, bustle, bodice of a dress of Empire style with a high waist, corsage of "sagdso" type - with flaps at the chest, long sleeves and short tails on the back, everyday coif, cap with a narrow crown, etc. Despite the apparent difference, these vestimentary elements have something in common: they are not codes of directive messages, nor do they allow a variety of explicit meanings (implicit meanings, however, can be contained in these cryptograms in any amounts and, moreover, they may form a continuum). To put it in other words, purely cryptographic signs immediately cause surprise: it is completely unclear why they are introduced into the dress.

Another kind of signs-ciphers does not generate signifieds-secrets whose meanings you need to seek out. These signs correspond to empty meanings, or simulative similarity, and the signs themselves, thus, go into the category of simulacra. We have already considered one vivid example of a cipher-simulacrum I mean cleavage. Examples of other simulacra of this type may be, for example, a scarf, pulled over her eyes hat, shawl, coiffure, pleated skirt of late Baroque, etc. All simulacra of female fashion allow variable diversity of explications (at zero degree of presence of the implications). A commoner treats all those things as signs indicating the signifieds of convenience, purpose and benefit, the ladies of the society often treat with simulative meaning. For example, linen shirts of a female peasant testify their practicality, strength and long-term use. Linen bottom skirts of a noble woman simulate durability and strength (is it possible to talk about the real reference, when some female Parisians of the times of Louis the Sixteenth got rid of their lower linen skirts after a week of wear?).

The variety of simulative semiotic technologies of female fashion is inexhaustible and limitless: high heels simulate long legs when a woman sits, and high height when she stands, high hairstyle simulates big height when she stands, and long upper part of her body when she sits. However, neither high hair, nor high heels are mandatory and, thus, they are not meaningful signs. The woman does not force anyone to consider her tall just because she raised her hair or preferred longer spike heels. 


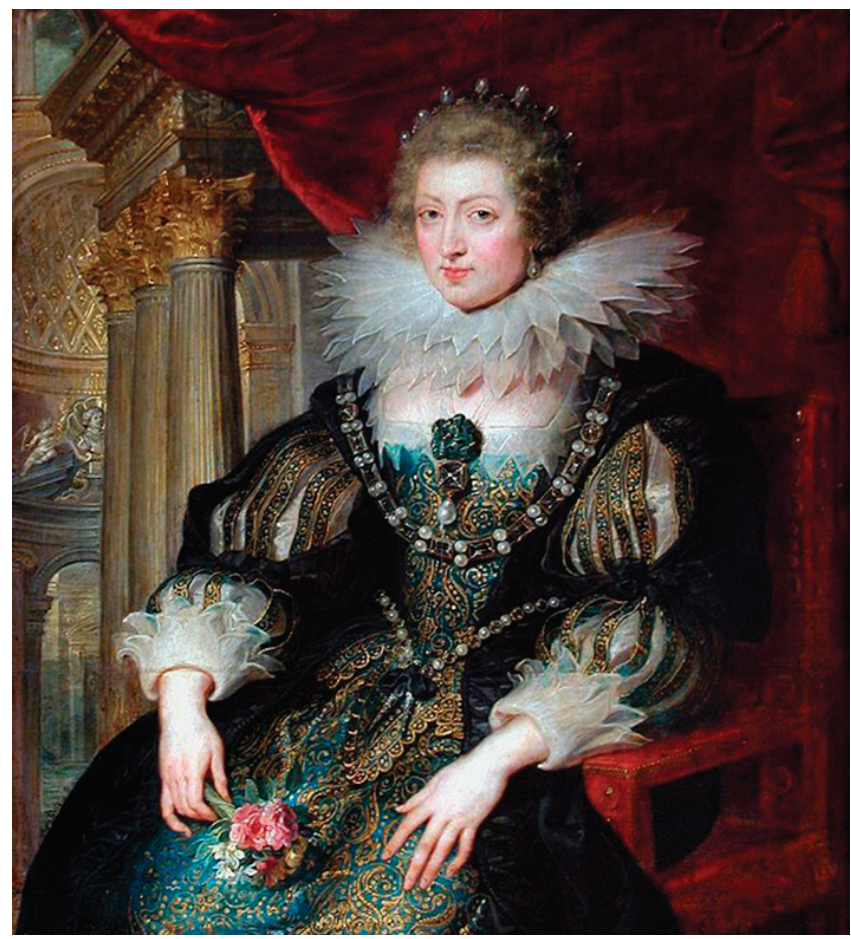

Fig. 3. All types of feminine fashion signs are present in this Diego Velazquez' portrait of Maria Anna of Spain

On the other hand, female fashion visual signs can be static (fixed) and dynamic (movable). Static signs are present as devoid of independent visual movement in a fixed coordinate system of a dress, while dynamic signs also have a movement. As examples of purely dynamic signs a train of dress, fan, shawl, female watch on a chain attached to the corsage, can serve. Dynamic signs are additional elements to increase the concentration of attention of people around the woman. In addition, a group of static-dynamic signs may be added to them, which act alternately as static or dynamic elements. An example is a woman's hairstyle. It is static in the sense that makes the hair immobile and eliminates their looseness. But if the woman with the laid hair sits, for example, in the nature, and the wind waves only one her hair strand near her temple, the coiffure becomes a dynamic sign. Other examples of ambivalent signs are the bracelet (sometimes motionless, sometimes sliding on the hand), earrings ${ }^{7}$, gloves (removed and being put on in public), underskirt, scarf, etc.

\footnotetext{
${ }^{7}$ Remember what a wonderful effect Scarlett O'Hara from Margaret Mitchell's novel “Gone with the wind" achieved, shaking her earrings.
} 


\section{Levels of semiotic chains of female fashion}

In addition to the two axes of classification of women's fashion signs, there is a third one, the level of the semiological system, at which a particular fashion sign operates. There is not a single detail of the toilet of a woman of society, which could be interpreted only from the viewpoint of pragmatism and utilitarianism. The interpretation of such signs always requires certain semantic mediations. Such details build a primary semiotic chain (denotative semiotic chain).

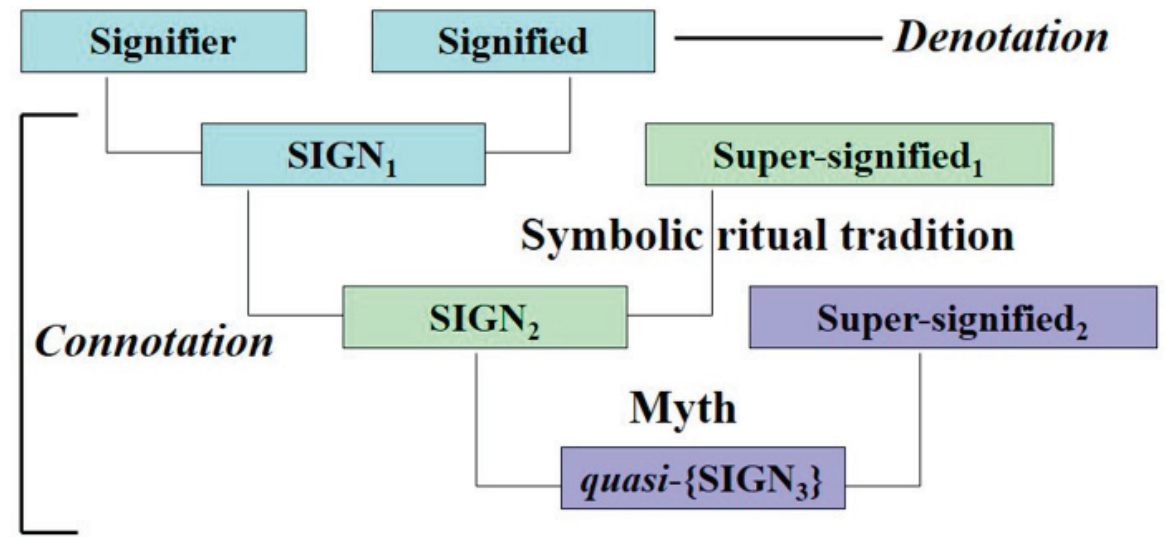

Fig. 4. The schematics of semiotic chains of the three levels

However, for representatives of other strata of the population who do not have a position in the society high enough so that they can afford the luxury of mediating any costume, considerations of benefit, purpose and convenience occupy the main place in the formation of the outfit. Elements of their clothing can be interpreted from the point view of "common sense" (functionality), and thus they create semiotic chains of zero level (pre-denotative semiotic chains). These are complete semiological systems, since they have 1) signifiers, 2) signifieds and 3) signs, but the signs themselves do not refer to the semiotic level of signifiers, but to the order below. For example, take the oilcloth apron of a drudge. Here is a signifier (apron), signified of the purpose (not to spoil the clothes), but the sign does not apply to the washing of the floors, but directly to the woman involved in this action. If washing the floors is the first semantic level, then drudge herself represents a zero level ${ }^{8}$, so we are not talking "an apron for washing floors" but "a drudge's apron".

\footnotetext{
${ }^{8}$ This difference between the semiotic levels of the subject and the object is explained in detail in the Barthes's book [Barthes 2003].
} 
Quite another thing is when such an apron was worn by Madame de Polignac, the first chambermaid of Marie Antoinette. She worn aprons to introduce a new fashion for egalitarianism in the high society, and the usual apron became a signifying detail of clothes, not purely functional. Such a detail of the costume already requires building a semiotic chain of the first level (denotative chain) and definite semantic mediating conclusions.

The apron in question is just one of many examples. Wherever the phænomenology of utilitarianism is introduced into the semiotic scheme, its level automatically becomes zero, because, in fact, this semiotic chain becomes broken, or at least consists of clearly separated signifiers and signs.

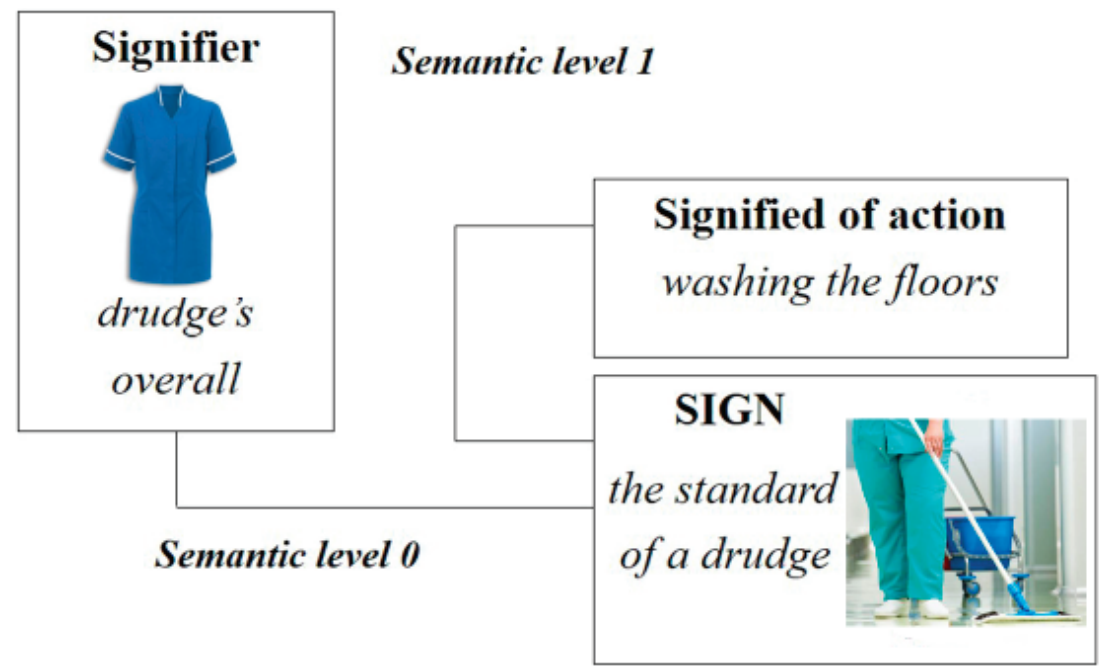

Fig. 5. Denotative (level 1) and pre-denotative (level 0) semantic levels in a semiotic chain of female fashion (the signifier is a drudge's overall)

There are also higher than the first, semiotic levels of fashion. In chains of the second level the woman uses not a detail of her toilet as a signifier, but the sign itself, and, thereby, the connotation of a sign begins (connotative semiotic chain).

Let us take a pair of customary women's glove for casual occasions. They can be included only in the semiotic chains of the first level. Ordinary gloves can act as a denotative sign, i.e. a sign referring to the visual sign itself. But if it is a long, rising up above the elbow, white ball gloves, they immediately go to the category of a connotative sign, i.e. as a signifier they rise to the second semiological level. The meaning begins to flow, to be "drawn" into the connotative sign-parasite of long ball 
gloves from the primary denotative sign of gloves. In this case, the quasisign has more meaning than a sign of costume items. In the secondary semiotic chain, the signifier is the sign of the gloves (but not the gloves themselves!), the signified is the presence of a woman at the ball (or other ceremony), and the sign of the second level is the figure of the dance (it is in the dance that ballroom gloves and the meaning of the ball combine). In other words, one sign once and for all is put to another sign by the identical semantic correspondence. Wearing a hat in the premises by women also forms a semiotic system of the second level. We may devise many such examples, and all of them will talk about a certain visual, symbolic ritual tradition created by woman.

\section{Feminine fashion sign connotation}

\section{("pulling" the meaning in the signs of higher dimensions):}

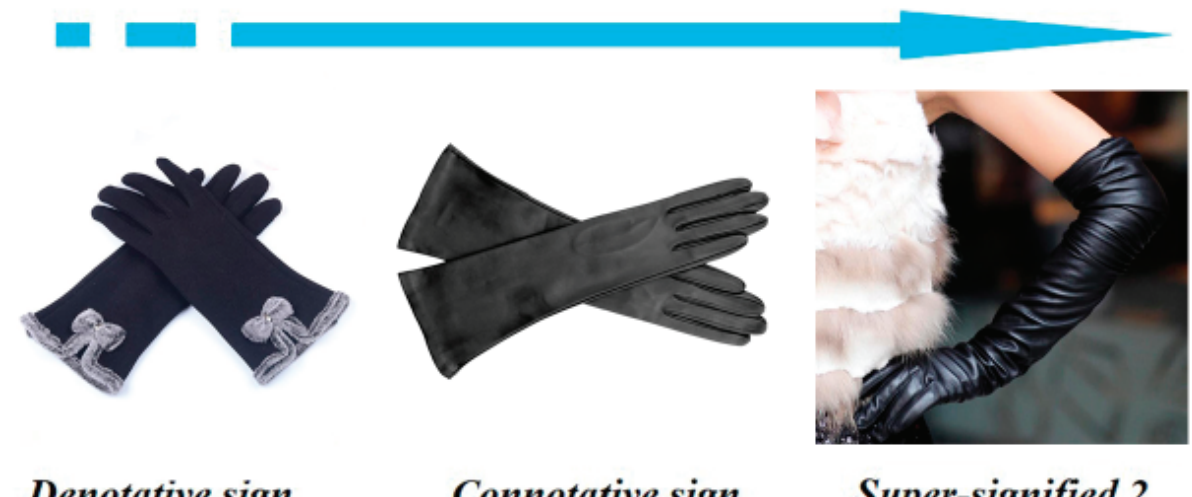

Denotative sign

Connotative sign

Super-signified 2

Fig. 6. The connotation of vestimentary signs in feminine fashion in this example of long female gloves

In the secondary semiotic chains, a woman, with the help of fashion explicating herself into the outside world, takes part in the process of transforming reality, which is usually described in terms of ideological alienation'. We face an example of constructing social reality with the help of fashion. In a symbolic tradition, ordinary signifieds become some immutable entities: once named ritual, ball, reception by the king, a walk through the Park of Versailles, an evening of comic theatre make some idols. Not only these semiotic "deities" are wonderfully created by feminine fashion, but they also create it themselves. They are created by the secondary semiotic schemes of fashion, and create primary ones.

\footnotetext{
${ }^{9}$ Claude Lévi-Strauss describes this process precisely in such terms [Lévi-Strauss 2003, 308-311].
} 
Instead of an arbitrary symbolic relationship between two signs of different levels, a mutually reversible inextricable relationship is established. With the help of fashion, the semiotics of reality is being built (the signs of the ball, the Royal reception, etc.), that captures the semiotics of fashion. In the semiotics of female vestimentary fashion, there is no phænomenological sense. It is impossible to understand why a woman in early Baroque era appeared at Royal receptions in outfits in which it was almost impossible to move, but it is easy to imagine, envisage or fancy. The construction of secondary semiotic correspondences suggests that signs-connotators (signs-signifiers linking the two semiotic chains) are ephemeral, but at the same time eternal, whimsical, but not absurd. With the help of connotation, female fashion carries out the secular sacralisation of society.

If a woman makes a sign of the second level (let us call it the sign of a symbolic tradition) a signifier an even more complex system, then she gets the third semiotic level, the level of myth [Barthes 2003, 239]. By Barthes's remark, where the sense ends, there begins the myth [Barthes $2003,248]$. So, in reality, few items of dress and other attributes of the image of women may act as constituent parts of the myth. Myth is a higher level than symbolic tradition, its influence is deeper and stronger. The fashion myth, by and large, symbolises nothing directly, and represents a field for symbolical games. A good example is a white wedding dress (or veil). It does not mean directly the chastity and virginity of the bride, as these qualities simply may not exist. It shews only the possibility of signs and meanings game: the bride must be a virgin, when she stands at the altar. Because this myth was quite permanent before the postmodernity, women wishing to marry for the second time, were forbidden to wear a white dress at the wedding in the church both in Orthodox and Roman Catholic traditions.

The myth of female fashion represents absolute connotation, or complete "pulling" the meaning of the primary sign, in which the signifier of the primary sign ceases to interest anyone. The wedding dress ceases to be a sign of the wedding ceremony (the first level) and marriage (the second level) and becomes a connotative sign-fetish of uniqueness and non-recurrence of the event associated with it in the life of a woman.

The stability of the semiotic myth (the third level of semiotic chain) can be illustrated by an interesting fact. Today in Western Europe, white wedding dress is used on average in 30-35\% of weddings, but in Russia its use has almost no alternative. We may hypothesise that the more 
highly mythologised consciousness of the Russians does not allow the elimination of the myth of the white wedding dress, that existed for centuries, from the culture. This is the case, in spite of the fact that according to sociological research performed in 2001-2002 in Russia, about half of the brides during the wedding were pregnant and about $80 \%$ of the brides answered in the poll bulletins that they were not virgins by the time of the wedding ceremony [Arkhangelskaya 2002, 37].

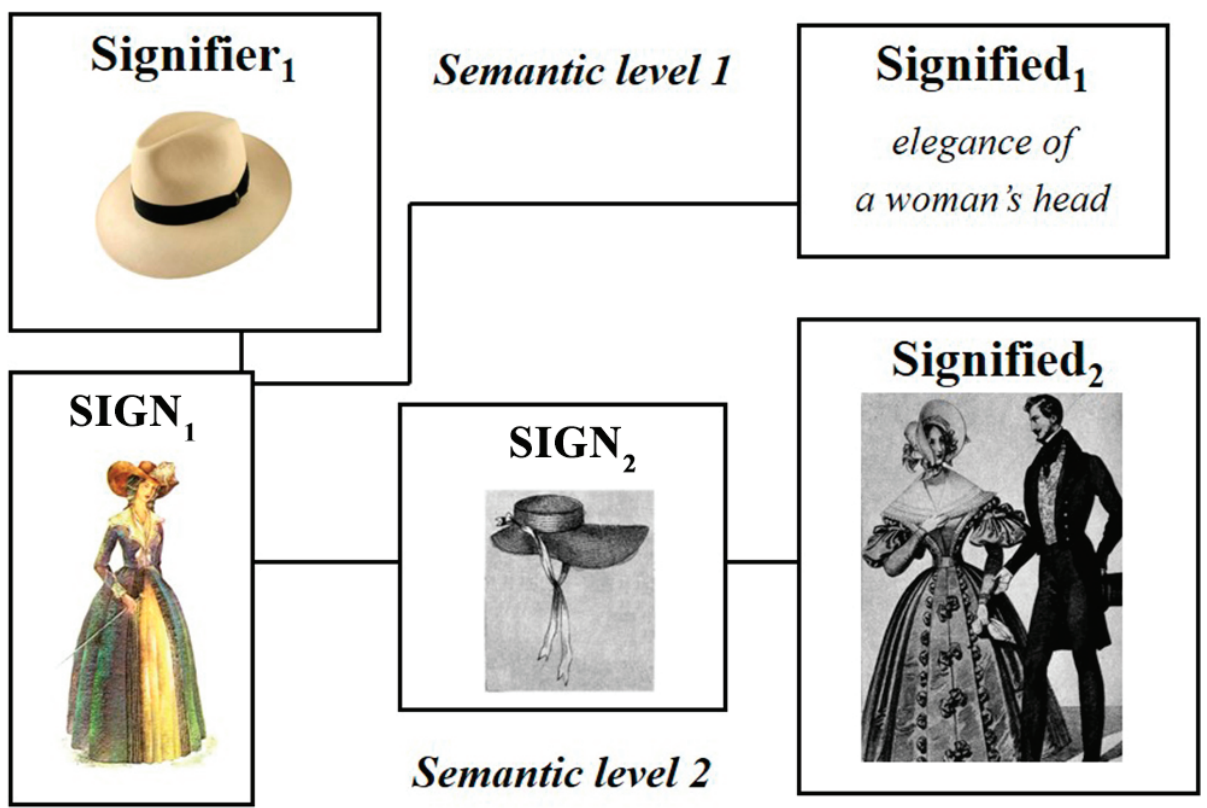

Fig. 7. Denotative (level 1) and connotative (level 2) semantic levels in a semiotic chain of female fashion (the initial signifier is a hat)

Just because of the absolute mythological nature of the signified and extreme connotativity of the sign, a wedding dress, which is sometimes more expensive than the sum of the woman's outfits of five years, is forced to gather dust in a dark closet throughout the future life of a woman. At the utmost, it will find a second connotative and nostalgic life at the marriage of the woman's daughter. Interestingly, in India, where wedding clothing is not mythologised, red wedding saree is used by women on special occasions throughout her whole life. Even in Europe at the time of Burgundy fashion, a woman, not mythologizing her luxurious wedding dress and leaving it at the ritual level, shewed it to admiring gazes of her guests and relatives at least once every two months. 


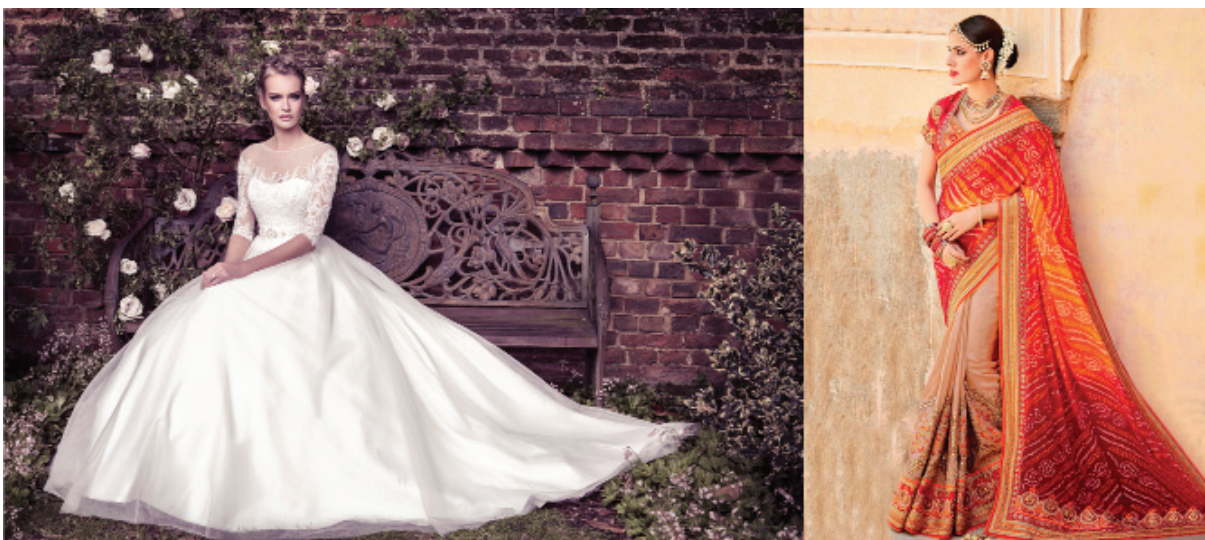

Fig. 8. With a white wedding dress, the European woman creates mythological semiotic system where the meaning is completely absorbed by the connotative signified of the non-recurrence of the event in question associated with the sign itself in the life of the woman. A red Indian wedding saree as a fashion sign does not reach the level of fashion mythology because it is often worn by the woman throughout her life after the marriage, e.g. at the celebrations, during meetings with her and her husband's relations, at religious processions etc. I acknowledge websites http://www.ellisbridals.co.uk and https://www.stylesgap.com for the illustrations provided. These websites retain full copyright for these images, therefore these images cannot be farther reproduced or copied in any form

Due to the presence of tertiary semiological schemes, the woman feels herself an absolute signifier in any clothing. The modesty of the dress or, on the contrary, even its absence does not prevent a woman to mythologise herself. Even the nudity becomes a mythical garment that was mentioned above.

\section{Conclusion}

The cross-exchange between the denotative reality of the world and the connotative unreality of the fashion myth corresponds to an inversion of the fashion sign, its transformation into a rational equivalent. Obviously, it is a most important operation carried out by the female semiotics of her fashion-myth. Since the male suit embodies the "naturalist" vision of the clothing, men's understanding the reality is far from mythologizing the fashion.

The connotation of fashion managing by the woman, i.e. creating a pure myth (the fashion of the mythological contents and form) leads to an extreme imbalance between the number of signifiers of fashion and its signifieds. The signifieds are invented by the woman, and their number is precisely calibrated and calculated, while there is the huge 
number of signifiers, they are all kinds and variations of clothing, an abundance of fashion features. We witness a mechanism of infinite metaphor of female meta-language, freely varying signifiers with limited amount of signifieds. Of course, it is important that this imbalance is formed in favour of the signifier: any vestimentary system, which has few signifiers and a lot of signifieds (for example, female nudity), generates anxiety, as each of its signs can be read in a different way. On the contrary, the fashion system with the reverse construction (with a large number of signifiers and a small number of signifieds) causes male euphoria, which is required for women to control the behaviour of the opposite sex, to please men, to turn their heads and in every possible way to increase their own chances of success. The greater the imbalance of the fashion-myth, the stronger the male euphoria. These are lists of metaphors with one signified the soothing poetry is based upon (for example, in litanies). Thus, according to its semiological structure, the metaphor of women's mythological fashion acts as a "soothing" operator, and since feminine fashion in most cases is metaphorical, it turns out to be a euphoric object, despite the supposedly arbitrary laws and rules by which it is created.

We found out the semiotic properties of female mythological fashion concerning the number of signs of fashion. Another important universal characteristic of women's mythological fashion is the mirror symmetry of signifieds and signifiers in the categories of quality of fashion features. The system of mythological fashion is, in fact, tautological: female fashion can be determined only by itself, since fashion starts its existence, after all, just from the existence of some clothes. Fashionable clothing is exactly what women declare with the help of the fashion system.

Thus, a pure mutual reflection exists between the signifiers and the signifieds in the semiotic system of female fashion. In this process, the signified seems to be emptied of all its content, but at the same time does not lose its power of designation. Through this process, a thing becomes a signifier of something that actually is the very fact of its own formation. Or, if we describe this phænomenon even more precisely, in the female vestimentary fashion the signifier (that is, a non-verbal semiotic statement of the woman) constantly spreads the meaning through the whole sign structure, but ultimately this meaning is nothing but the very same signifier! Therefore, fashion presented in the form of the female myth-making, acts as a paradoxical artefact phænomenon, a semantic system whose only purpose is the evasiveness of its sense.

This system does not refuse a visual embodiment, a sort of spectacle, of a symbolic process. Such reflexive myth-making an activity of women 
has a mental model, it is mathematical (but in no way formal) logic. Like Boolean logic, women's mythological fashion is characterised as an infinite variation of the same theme; like this logic, it seeks to establish a relationship of equivalence, validity, supra-segmentation, negation, etc., but not the deep truth. Finally, like mathematical logic, female semiotic fashion-myth has a rather modest content, although it is not in the least meaningless.

The comparison of female fashion system with Boolean logic suggests serious reflections that definitely go beyond the scope of this study. Can female fashion myth-making act as a valid explicit marker of the existence of a special "female logic" that does not obey the rules of formal Aristotelian and Kantian logic, which is by far the pinnacle of the development of "male logic"? Can we speculate about two types of gender logic just on the basis of the unique logical structure of female fashion? Does such "female logic" of connoted meanings and fluid semiotic correspondences, really exist? One theorises a lot about a special female logic, but no one knows what it is. The study of such a question is obviously beyond the scope of this work, but it may be of enough philosophical interest to become a subject of a separate study.

\section{REFERENCES}

Afonasina 2014 - Afonasina A. S. Ancient literary sources on painted statues. ПРА Russian.

Afonasina 2018 - Afonasina A. S. The letters of the "Pythagorean" women Melissa to Kleareta and Myia to Phyllis. A commented translation into the Russian. $\Sigma X O \Lambda H$. Ancient Philosophy and Classical Tradition. 2018. 12. 1. P. 276-286.

Arkhangelskaya 2002 - Arkhangelskaya V. N. The interactions in the modern Russian family. The Inhabitants. 2002. 2. P. 33-52. In Russian.

Avanesov 2018 - Avanesov S. S. The body and the yarn. A visualization of a metaphor in the Annunciation iconography. $\Sigma X O \Lambda H$. Ancient Philosophy and Classical Tradition. 2018. 12. 2. P. 523-534. In Russian. Barthes 1975 - Barthes R. Roland Barthes par Roland Barthes. Paris, 1975.

Barthes 2003 - Barthes R. Système de la mode. Transl. into Russian. Moscow, 2003.

Baudrillard 1980 - Baudrillard J. De la seduction: L'horizon sacré des apparences. Paris, 1980. 
Baudrillard 1976 - Baudrillard J. L'échange symbolique et la mort. Paris, 1976.

Benhabib 2002 - Benhabib S. The Claims of Culture: Equality and Diversity in the Global Era. Princeton, NJ, 2002.

Bernatonite 2016 - Bernatonite A. K. Andrzej Wajda and screen adaptation of Russian classics. ПРА $\Xi H M A$. Journal of Visual Semiotics. 2016. 4 (10). P. 93-108. In Russian.

Bernatonite 2017 - Bernatonite A. K. The semantics of the images of family members in their relations with the guest in the text of P. P. Pasolini's script and in his film "Teorema". ПРА $\Xi H M A$. Journal of Visual Semiotics. 2017. 2 (12). P. 125-145. In Russian.

Bourdieu 1975 - Bourdieu P. Le couturier et sa griffe: contributions à une théorie de la magie. Actes de la recherche en sciences sociales. 1975. 1. P. 7-34.

Dogo 2015 - Dogo D. Building the image of Russian political conspirators in early Soviet cinematography. ПРА $\Xi$ MA. Journal of Visual Semiotics. 2015. 2 (4). P. 69-81.

Dulgheru 2014 - Dulgheru E. The sacred in the films of Andrei Tarkovsky. The archetype of the house. ПРАछHMA. Journal of Visual Semiotics. 2014.2 (2). P. 88-100. In Russian.

Eco 2006 - Eco U. La Struttura assente: introduzione alla ricerca semiologica. Transl. into Russian. St. Petersburg, 2006.

Goodman 1972 - Goodman N. Problems and Projects. Indianapolis, IN, 1972.

Hjelmslev 1959 - Hjelmslev L. Essais linguistiques. Copenhagen, 1959. Hugo 2002 - Hugo V. L'Homme qui rit. Paris, 2002.

Irigaray 1984 - Irigaray L. Etique de la Différence Sexuelle. Paris, 1984. Khitruk 2017 - Khitruk E. B. "Male issue" in the works of Andrei Tar-

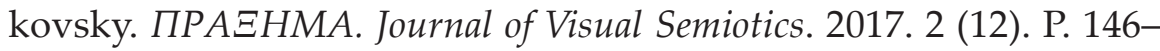
154. In Russian.

Kireeva 1976 - Kireeva E. V. The History of Costume. Moscow, 1976. In Russian.

Lacan 1953 - Lacan J. Fonction et champ de la parole et du langage en psychanalyse. Rapport du Congrès de Rome tenu à l'Istituto di Psicologia della Universitá di Roma les 26 et 27 septembre 1953. URL: http://aejcpp.free.fr/lacan/1953-09-26b.htm.

Lévi-Strauss 2003 - Lévi-Strauss C. Anthropologie structural. Paris, 2003.

Lévi-Strauss 2002 - Lévi-Strauss C. Les structures élémentaires de la parenté. Paris, 2002. 
Martindale 1990 - Ovid Renewed: Ovidian Influence on Literature and Art from the Middle Ages to the Twentieth Century. Ed. by Ch. Martindale. Cambridge, 1990.

Martinet 1960 - Martinet A. Eléments de linguistique générale. Paris, 1960.

Meeusen 2018 - Meeusen M. Aristotelian Natural Problems and Imperial Culture: Selective Readings. $\Sigma X O \Lambda H$. Ancient Philosophy and Classical Tradition. 2018. 12. 1. P. 28-47.

Myakin 2018 - Myakin T. G. De poetis Lesbiorum, de herma, deo fertilitatis, et de mysteriis Artemidis apud Mytilenaeos olim celebratis.

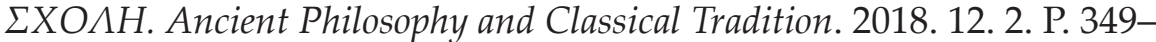
364.

Myakin 2019 - Myakin T. G. The goddess Venus in Lucretius' poem “De rerum natura". $\Sigma X O \Lambda H$. Ancient Philosophy and Classical Tradition. 2019. 13. 1. P. 153-179. In Russian.

Obraztsov 1978 - Obraztsov S. V. Relay Race of Art. Moscow, 1978. In Russian.

Panagiotarakou 2019 - Panagiotarakou E. Rational actors? Hippias and

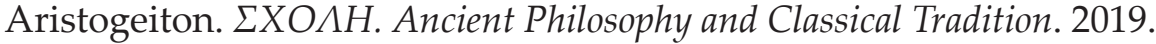
13. 1. P. 19-31.

Protopopova, Garadja 2018 - Protopopova I. A., Garadja A. V. Reading a woman. $\Sigma X O \Lambda H$. Ancient Philosophy and Classical Tradition. 2018. 12. 2. P. 433-443.

Sharov 2019 - Sharov K. S. Ancient Rome and female administrators.

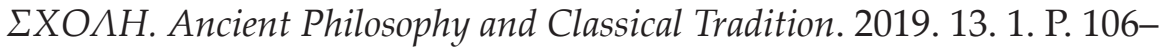
114. In Russian.

Thackeray 1992 - Thackeray W. M. Vanity Fair. London, 1992.

Troubetzkoy 1949 - Troubetzkoy N.S. Principes de phonologie. Paris, 1949.

Vedeshkin 2018 - Vedeshkin M. A. Bribe and Punishment: To the Question of Persistence of Pagan Cults in Late Antiquity. $\Sigma X O \Lambda H$. Ancient Philosophy and Classical Tradition. 2018. 12. 1. P. 259-275.

Zborovsky 1988 - Zborovsky E. M. According to the Laws of Beauty. Moscow, 1988. In Russian. 